\title{
BUILDING BLOCKS for a RESILIENT CITY
}

RESILIENCE communities to withstand and recover from disasters as well as to learn from past disasters to strengthen future response and recovery efforts.

\section{A RESILIENT COMMUNITY CAN}

(1) determine what it needs to reduce damage and to use its assets or resources wisely. The community is resourceful with what it has, no matter its condition or whether it has a lot of resources.

(2) not only bounce back quickly, but take the opportunity to strengthen health, environmental, social and economic systems.

(3) learn from past emergencies so that it can be better prepared for the next response.

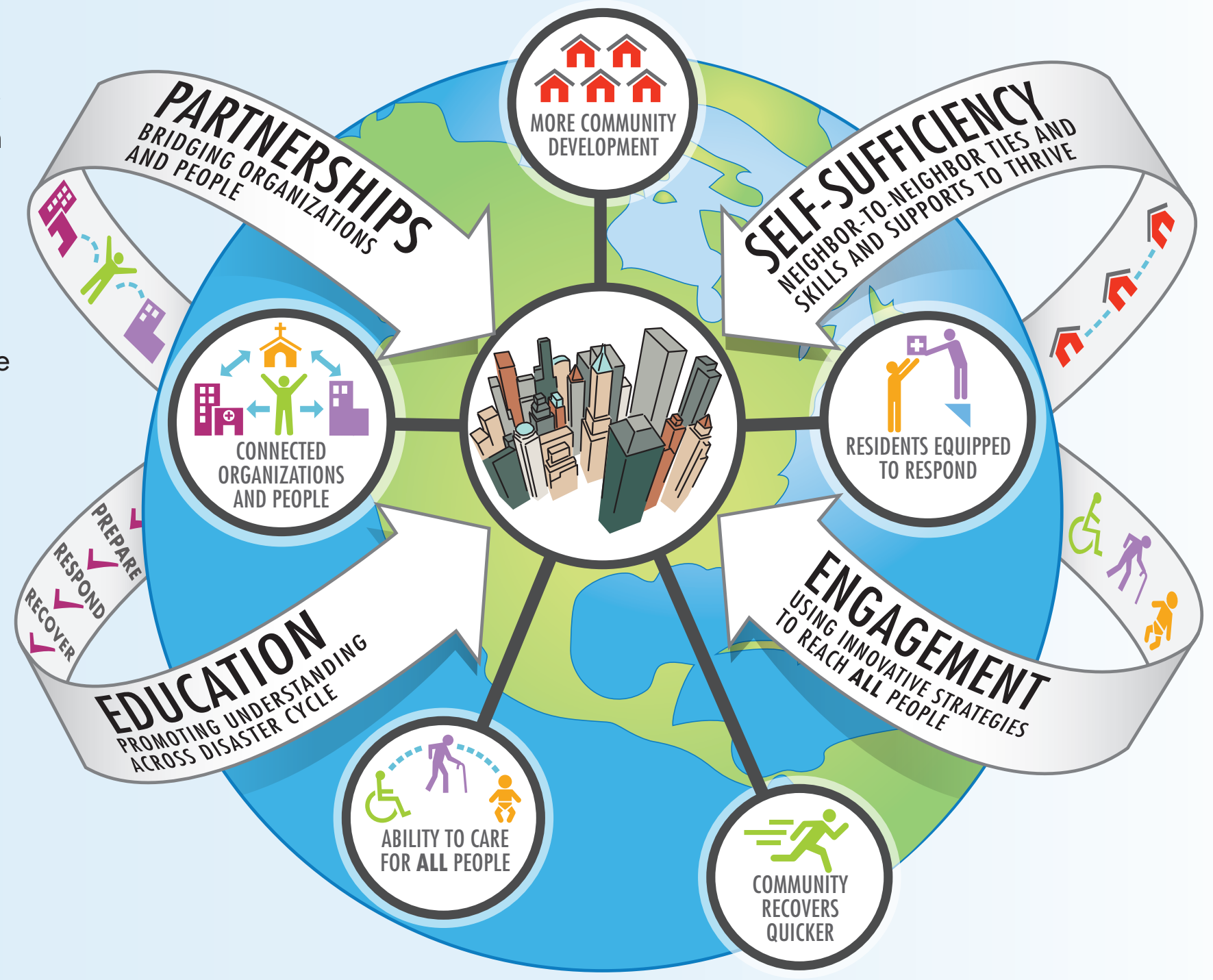

The RAND Corporation is a research organization that develops solutions to public policy challenges to help make communities throughout the world safer and more secure, healthier and more prosperous. RAND is nonprofit, nonpartisan, and committed to the public interest. www.rand.org

For more information, please visit www.rand.org/resilience-in-action.html 


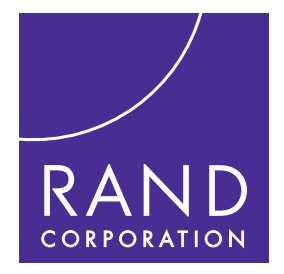

CHILDREN AND FAMILIES

EDUCATION AND THE ARTS

ENERGY AND ENVIRONMENT

HEALTH AND HEALTH CARE

INFRASTRUCTURE AND

TRANSPORTATION

INTERNATIONAL AFFAIRS

LAW AND BUSINESS

NATIONAL SECURITY

POPULATION AND AGING

PUBLIC SAFETY

SCIENCE AND TECHNOLOGY

TERRORISM AND HOMELAND SECURITY
The RAND Corporation is a nonprofit institution that helps improve policy and decisionmaking through research and analysis.

This electronic document was made available from www.rand.org as a public service of the RAND

Corporation.

\section{Support RAND}

Browse Reports \& Bookstore

Make a charitable contribution

\section{For More Information}

Visit RAND at www.rand.org

Explore the RAND Corporation

View document details

\section{Infographic}

RAND infographics are design-focused, visual representations of data and information based on a published, peer-reviewed product or a body of published work.

\section{Limited Electronic Distribution Rights}

This document and trademark(s) contained herein are protected by law as indicated in a notice appearing later in this work. This electronic representation of RAND intellectual property is provided for non-commercial use only. Unauthorized posting of RAND electronic documents to a non-RAND website is prohibited. RAND electronic documents are protected under copyright law. Permission is required from RAND to reproduce, or reuse in another form, any of our research documents for commercial use. For information on reprint and linking permissions, please see RAND Permissions. 